\title{
HUBUNGAN FAKTOR PREDISPOSISI, FAKTOR PEMUNGKIN, DAN FAKTOR PENGUAT DENGAN PERILAKU MEROKOK PELAJAR SMKN 2 KOTA PROBOLINGGO TAHUN 2017
}

\author{
Bima Indragani Purnomo, Roesdiyanto, Rara Warih Gayatri \\ Fakultas Ilmu Keolahragaan Universitas Negeri Malang \\ E-mail: bimaindraganipurnomo@gmail.com
}

\begin{abstract}
According to the WHO, Indonesia is the country with the highest rates of adolescent smokers in the world. About $80 \%$ of teen smokers start the habit before the age of 19 years. Based on preliminary research, eight of the fifteen students of SMKN 2 Kota Probolinggo are smokers. According Simarmata (2012: 80), predisposing factors, enabling factors, and reinforcing factors have a relationship to adolescent smoking behavior. This study aims to determine the relationship of predisposing factors, enabling factors, and reinforcing factors with smoking behavior in SMKN 2 Probolinggo students in 2017. This research uses descriptive correlative and regression design, cross sectional approach, and sample of 291 students using proportional stratified random sampling in taking samples. Based on descriptive analysis it is known that there are 171 students who are non-smokers and 120 students as smokers. Based on correlative analysis it can be seen that gender variables, knowledge, attitudes, pocket money, and smoking status of family members have a significant relationship to smoking behavior of learners. In the regression analysis it can be seen that gender, attitude, allowance, and family members' smoking status are the most influential variables on smoking behavior of students. Based on the result of the research, it can be concluded that the behavior of SMKN 2 Kota Probolinggo student smoking is influenced by many factors: gender, knowledge about cigarette, attitude toward cigarette, amount of allowance, and member's smoking status.
\end{abstract}

Keywords: smoking behavior, predisposing factors, enabling factors, reinforcing factors

\begin{abstract}
Abstrak: Menurut WHO, Indonesia merupakan negara dengan angka perokok remaja tertinggi di dunia. Sekitar $80 \%$ perokok remaja memulai kebiasaan tersebut sebelum berumur 19 tahun. Berdasarkan penelitian pendahuluan diketahui delapan dari lima belas pelajar di SMKN 2 Kota Probolinggo adalah perokok. Menurut Simarmata (2012:80), faktor predisposisi, faktor pemungkin, dan faktor penguat memiliki hubungan terhadap perilaku merokok remaja. Penelitian ini betujuan untuk mengetahui hubungan faktor predisposisi, faktor pemungkin, dan faktor penguat dengan perilaku merokok pelajar di SMKN 2 Kota Probolinggo tahun 2017. Penelitian ini menggunakan desain deskriptif korelatif dan regresi, pendekatan cross sectional, dan sampel sebanyak 291 pelajar dengan menggunakan proportional stratified random sampling dalam mengambil sampel. Berdasarkan analisis deskriptif diketahui bahwa terdapat sebanyak 171 pelajar yang berstatus bukan perokok dan 120 pelajar berstatus sebagai perokok. Berdasarkan analisi korelatif dapat diketahui bahwa variabel jenis kelamin, pengetahuan, sikap, uang saku, dan status merokok anggota keluarga memiliki hubungan yang signifikan terhadap perilaku merokok pelajar. Pada analisis regresi dapat diketahui bahwa jenis kelamin, sikap, uang saku, dan status merokok anggota keluarga merupakan variabel yang paling berpengaruh terhadap perilaku merokok pelajar. Berdasarkan hasil penelitian dapat disimpulkan bahwa perilaku merokok pelajar SMKN 2 Kota Probolinggo di pengaruhi oleh banyak faktor yaitu jenis kelamin, pengetahuan tentang rokok, sikap terhadap rokok, besaran uang saku, dan status merokok anggota keluaraga.
\end{abstract}

Kata Kunci: perilaku merokok, faktor predisposisi, faktor pemungkin, faktor penguat

Merokok merupakan salah satu bentuk perilaku yang banyak ditemui di masyarakat. Berdasarkan Peraturan Pemerintah No. 109 tahun 2012 tentang Pengamanan Bahan yang Mengandung
Zat Adiktif berupa Produk Tembakau bagi Kesehatan, rokok adalah salah satu produk tembakau yang dimaksudkan untuk dibakar dan dihisap dan/atau dihirup asapnya, termasuk rokok kretek, 
rokok putih, cerutu atau bentuk lainnya (Peraturan Pemerintah Republik Indonesia, 2012). Menurut Departemen Kesehatan Republik Indonesia (dalam Vivaldi, 2008:8), status merokok seseorang dapat dilihat dari ada tidaknya aktivitas merokok seseorang dan telah merokok sekurang-kurangnya selama satu tahun. WHO (dalam Vivaldi, 2016), membagi perokok menjadi tiga kategori yaitu perokok ringan, perokok sedang dan perokok berat.

1. Perokok ringan, adalah seseorang yang melakukan aktivitas merokok sebanyak 1-10 batang per hari.

2. Perokok sedang, adalah seseorang yang melakukan aktivitas merokok sebanyak 11-20 batang per hari.

3. Perokok berat, adalah seseorang yang melakukan aktivitas merokok sebanyak 20 hingga lebih batang rokok per hari.

Rokok memiliki dampak yang merugikan baik dari sisi kesehatan, ekonomi, sosial, dan lingkungan (Kemenkes, 2015). Dari segi kese-hatan, diketahui bahwa sebatang rokok mengandung 4000 jenis zat kimia yang berbahaya bagi tubuh (Rahmadi dkk, 2013). Dari segi ekonomi, biaya konsumsi untuk tembakau di Indonesia yang dikeluarkan sebesar Rp338,75 triliun (Kemenkes, 2011). Jumlah tersebut adalah sekitar 6 kali dari pemasukan cukai rokok yaitu sebesar Rp53,9 triliun (Kemenkes, 2011).

Jumlah perokok di seluruh dunia pada tahun 2015 mencapai 1,2 miliyar orang dimana 800 juta diantaranya berada di negara berkembang (Kemenkes, 2015). ASEAN merupakan kawasan dengan $10 \%$ perokok di dunia dimana 46,16\% diantaranya berada di Indonesia (Kemenkes, 2015:1).

The Tobacco Atlas $6^{\text {th }}$ Edition (2015:30), menyebutkan bahwa Indonesia merupakan negara dengan jumlah konsumsi rokok terbesar keempat di dunia setelah Cina, Rusia, dan Amerika. Prevalensi merokok di Indonesia mengalami peningkatan dari $27 \%$ pada tahun 1995 menjadi 36,3\% pada tahun 2013 (Kemenkes, 2016). Peningkatan jumlah perokok juga pada usia remaja. Data Kementerian Kesehatan menunjukkan, prevalensi merokok remaja usia 16-19 tahun meningkat 3 kali lipat dari 7,1\% (1995) menjadi 20,5\% (2014) (Kemenkes, 2016). Berdasarkan Global Youth Tobacco Survey (GYTS, 2014:1), diketahui sebesar 19\% remaja Indonesia mengkonsumsi rokok dengan rincian sebesar 35\% remaja laki-laki dan 3\% remaja perempuan merupakan perokok. WHO (dalam Kemenkes, 2015), menyatakan bahwa Indonesia merupakan negara dengan angka perokok remaja tertinggi di dunia.

Perilaku merokok pada remaja dipengaruhi oleh banyak faktor. Penelitian, Simarmata (2012), menunjukkan bahwa terdapat hubungan antara pengaruh orang tua, pengaruh teman sebaya, keterjangkauan terhadap rokok, umur, jenis kelamin, sikap, dan pengetahuan terhadap perilaku merokok pada pelajar. Green (dalam Notoatmodjo, 2011) menjelaskan bahwa perilaku seseorang dipengaruhi oleh tiga faktor pokok, yaitu:

1. faktor predisposisi (predisposing factors), yaitu faktor-faktor yang mempermudah terjadinya perilaku seseorang, antara lain pengetahuan, sikap, keyakinan, kepercayaan, nilai-nilai, tradisi, dan sebagainya.

2. faktor pemungkin (enabling factors), adalah faktor-faktor yang memungkinkan atau yang memfasilitasi perilaku seseorang. Contohnya adalah sarana prasarana kesehatan, misalnya Puskesmas, Posyandu, rumah sakit, uang untuk berobat, tempat sampah,.

3. faktor penguat (reinforcing factors), adalah faktor yang menguatkan seseorang untuk berperilaku sehat ataupun berperilaku sakit, mendorong atau memperkuat terjadinya perilaku seperti dorongan dari orang tua, tokoh masyarakat, dan perilaku teman sebaya yang menjadi panutan.

Menurut WHO (dalam Kemenkes, 2015b), remaja adalah penduduk dalam rentang usia 10-19 tahun sedangkan, 
menurut Permenkes RI Nomor 25 tahun 2014, remaja adalah penduduk dalam rentang usia 10-18 tahun. Menurut Astuti (dalam Chotidjah, 2012), remaja yang merokok pada usia muda merupakan kelompok yang rentan dan berpotensi menjadi perokok jangka panjang. Terlebih, menurut Taylor (dalam Chotidjah, 2012), sering kali ditemui perilaku merokok yang dimulai pada usia anak-anak dan remaja disertai dengan perilaku ke-kerasan, penggunaan obat-obatan ter-larang bahkan juga narkoba. Berda-sarkan penelitian Maseda (2013), pengetahuan dan sikap tentang rokok memiliki hubungan dengan perilaku merokok remaja SMAN 1 Tompasobaru usia 15-18 tahun. Menurut Ramantika (2014), keterjangkauan uang saku merupakan faktor yang memiliki hubungan dengan perilaku merokok pelajar SMKN 1 Mempawah Timur usia 15-17 tahun. Menurut Komasari (2003), terdapat perilaku merokok orang tua merupakan prediktor perilaku merokok pada remaja usia 15-18 tahun. Sedangkan, menurut Simarmata (2012), faktor predisposisi, faktor pemungkin, dan faktor penguat memiliki hubungan dengan perilaku merokok remaja.

Berdasarkan data Riset Kesehatan Dasar (2007) menunjukkan, Probolinggo termasuk sepuluh besar daerah dengan jumlah prevalensi merokok setiap hari pada penduduk usia diatas 10 tahun yaitu sebesar $34,3 \%$. Menurut Kepala Dinas Pendidikan Kota Probolinggo, masih banyak pelajar yang berperilaku merokok, termasuk di kalangan pelajar Sekolah Menengah Atas (SMA) atau sederajat dimana memiliki umur antara 15 sampai 19 tahun. SMKN 2 Kota Probolinggo merupakan salah satu sekolah menengah kejuruan yang berada di Kota Probolinggo. Berdasarkan penelitian pendahuluan yang dilakukan, 8 dari 15 pelajar di SMKN 2 Kota Probolinggo adalah perokok.
Berdasarkan wawancara dengan Wakil Kepala Sekolah SMKN 2 Kota Probolinggo, diketahui bahwa perilaku merokok pelajar SMKN 2 Kota Probolinggo masih tinggi.

Berdasarkan pemaparan di atas, peneliti akan melakukan penelitian dengan judul "Hubungan Faktor Predisposisi, Faktor Pemungkin, dan Faktor Penguat dengan Perilaku Merokok Pelajar SMKN 2 Kota Probolinggo tahun 2017". Tujuan dari penelitian ini adalah untuk mengetahui gambaran perilaku merokok pelajar dan mengetahui hubungan jenis kelamin, pengetahuan tentang rokok, sikap terhadap rokok, besaran uang saku pelajar dan status merokok anggota keluarga dengan perilaku merokok pelajar.

\section{METODE}

Penelitian ini menggunakan desain penelitian deskriptif korelatif dengan pendekatan cross sectional. Pengambilan data menggunakan kuesioner terhadap 291 pelajar kelas X dan XI SMKN 2 Kota Probolinggo yang dilakukan pada bulan April hingga Juli 2017. Analisis data yang digunakan adalah analisis deskriptif, uji korelasi, dan uji regresi untuk mengetahui gambaran, besar hubungan dan variabel yang paling berpengaruh dari variabel bebas yaitu jenis kelamin, pengetahuan, sikap, uang saku pelajar, dan status merokok anggota keluarga, dengan variabel terikat yaitu merokok pelajar.

\section{HASIL PENELITIAN \\ Analisis Univariat}

Pada tahap ini setiap variabel dianalisis untuk diketahui karakteristik dan distribusinya (analisis deskriptif). Variabel-variabel yang dianalisis secara deskriptif adalah perilaku merokok, jenis kelamin, pengetahuan, sikap, uang saku, dan status merokok anggota keluarga dari responden. Hasil analisis univariat adalah sebagai berikut. 
Tabel 1. Distribusi Karakteristik Merokok Responden

\begin{tabular}{|c|c|c|}
\hline Variabel & Frekuensi (f) & Persentase $(\%)$ \\
\hline \multicolumn{3}{|l|}{ Perilaku Merokok } \\
\hline - Tidak Merokok & 171 & $58,8 \%$ \\
\hline - Merokok & 120 & $41,2 \%$ \\
\hline - Perokok Ringan & 117 & $40,2 \%$ \\
\hline - $\quad$ Perokok Sedang & 3 & $1,0 \%$ \\
\hline - Perokok Berat & 0 & $0 \%$ \\
\hline Total & 291 & $100 \%$ \\
\hline \multicolumn{3}{|l|}{ Jenis Kelamin } \\
\hline - Perempuan & 38 & $13,1 \%$ \\
\hline - Laki-laki & 253 & $86,9 \%$ \\
\hline Total & 291 & $100 \%$ \\
\hline \multicolumn{3}{|l|}{ Pengetahuan tentang Rokok } \\
\hline - Tinggi & 38 & $13,1 \%$ \\
\hline - Sedang & 161 & $55,3 \%$ \\
\hline - Kurang & 92 & $31,6 \%$ \\
\hline Total & 291 & $100 \%$ \\
\hline \multicolumn{3}{|l|}{ Sikap terhadap Rokok } \\
\hline - Tidak setuju/tidak mendukung rokok & 194 & $66,7 \%$ \\
\hline - Setuju/mendukung rokok & 97 & $33,3 \%$ \\
\hline Total & 291 & $100 \%$ \\
\hline \multicolumn{3}{|l|}{ Uang Saku } \\
\hline - Rendah & 111 & $38,1 \%$ \\
\hline - Tinggi & 180 & $61,9 \%$ \\
\hline Total & 291 & $100 \%$ \\
\hline \multicolumn{3}{|l|}{ Status Merokok Anggota Keluarga } \\
\hline - Tidak ada & 75 & $25,8 \%$ \\
\hline - Ada & 216 & $74 \%$ \\
\hline Total & 291 & $100 \%$ \\
\hline
\end{tabular}

Berdasarkan analisis deskriptif untuk mengetahui gambaran masingmasing variabel, dari 291 responden yang menjadi sampel terdapat 171 pelajar $(58,8 \%)$ dengan status bukan perokok dan 120 pelajar $(41,2 \%)$ dengan status perokok. Dari 120 pelajat yang berstatus perokok, sebanyak 117 pelajar diantaranya meru-pakan perokok ringan, 3 responden merupakan perokok sedang dan tidak ada responden sebagai perokok berat. Selain itu, juga diketahui karakteristik responden terkait jenis kelamin, pengetahuan tentang rokok, sikap terhadap rokok, uang saku, dan status merokok anggota keluarga.

\section{Analisis Bivariat}

Pada tahap ini setiap variabel bebas yaitu jenis kelamin, pengetahuan tentang, sikap terhadap rokok, uang saku, dan status merokok anggota keluarga dicari hubungannya (korelasi) dengan variabel terikat yaitu perilaku merokok responden. Hubungan variabelvariabel bebas dengan variabel terikat ditunjukkan pada tabel berikut.

Tabel 2 Hubungan Jenis Kelamin dengan Perilaku Merokok Pelajar 


\begin{tabular}{|c|c|c|c|c|c|c|c|c|c|}
\hline \multirow{3}{*}{$\begin{array}{c}\text { Jenis } \\
\text { Kelamin }\end{array}$} & \multicolumn{4}{|c|}{ Perilaku Merokok } & \multirow{2}{*}{\multicolumn{2}{|c|}{ Total }} & \multirow{3}{*}{$\begin{array}{c}\text { Nilai } \\
\mathrm{C}\end{array}$} & \multirow[b]{2}{*}{ Nilai $p$} & \multirow[b]{2}{*}{ Nilai OR } \\
\hline & \multicolumn{2}{|c|}{$\begin{array}{c}\text { Bukan } \\
\text { Perokok }\end{array}$} & \multicolumn{2}{|c|}{ Perokok } & & & & & \\
\hline & $\mathrm{n}$ & $\%$ & $\mathrm{n}$ & $\%$ & $\mathrm{n}$ & $\%$ & & & \\
\hline Perempuan & 36 & $\begin{array}{c}94, \\
7\end{array}$ & 2 & 5,3 & 38 & 100 & 0,273 & 0,000 & \\
\hline Laki-laki & 135 & $\begin{array}{c}53 \\
4\end{array}$ & 118 & $\begin{array}{c}46, \\
6\end{array}$ & 253 & 100 & $(C C)$ & $(C h i)$ & 0,064 \\
\hline Total & 171 & $\begin{array}{c}58 \\
8\end{array}$ & 120 & $\begin{array}{c}41, \\
2\end{array}$ & 291 & 100 & & & \\
\hline
\end{tabular}

Berdasarkan Tabel 2 diperoleh nilai $\mathrm{p}=0,000(\mathrm{p}<0,05)$, artinya terdapat hubungan yang signifikan antara jenis kelamin dengan perilaku merokok. Nilai koefisien kontingensi (C) sebesar 0,273 menunjukkan korelasi positif dengan kekuatan korelasi yang lemah. Selain itu juga diperoleh persamaan regresi dari hubungan kedua variabel seperti berikut:

$\mathbf{Y}=\mathbf{a}+\mathbf{b} \mathbf{X}_{1}$

$Y=-\mathbf{0 , 1 3 5}-2,756$ (Jenis Kelamin)
Dari persamaan , dapat diketahui, jika pelajar dengan jenis kelamin lakilaki nilai $\left(\mathrm{X}_{1}\right)$ adalah $(0)$ maka nilai $(\mathrm{Y})$ sebesar - 0,135 sehingga, laki-laki memiliki probabilitas sebesar 46,63\% untuk berperilaku merokok. Sedangkan, jika pelajar dengan jenis kelamin perempuan nilai $\left(\mathrm{X}_{1}\right)$ adalah (1) maka nilai $(\mathrm{Y})$ sebesar -2,891 sehingga, perempuan memiliki probabilitas sebesar 46,63\% untuk berperilaku merokok.

Tabel 3 Hubungan Pengatahuan tentang Rokok dengan Perilaku Merokok Pelajar

\begin{tabular}{|c|c|c|c|c|c|c|c|c|c|}
\hline \multirow{3}{*}{$\begin{array}{c}\text { Pengetahuan } \\
\text { Tentang } \\
\text { Rokok }\end{array}$} & \multicolumn{4}{|c|}{ Perilaku Merokok } & \multicolumn{2}{|c|}{ Total } & \multirow[t]{2}{*}{ Nilai $\lambda$} & \multirow[t]{2}{*}{ Nilai $p$} & \multirow[t]{2}{*}{ Nilai OR } \\
\hline & \multicolumn{2}{|c|}{$\begin{array}{c}\text { Bukan } \\
\text { Perokok }\end{array}$} & \multicolumn{2}{|c|}{ Perokok } & & & & & \\
\hline & $\mathrm{n}$ & $\%$ & $\mathrm{n}$ & $\%$ & $\mathrm{n}$ & $\%$ & & & \\
\hline Tinggi & 30 & $\begin{array}{c}78, \\
9\end{array}$ & 8 & $\begin{array}{c}21, \\
1\end{array}$ & 38 & 100 & $-0,138$ & 0,026 & \\
\hline Sedang & 92 & $\begin{array}{c}57, \\
1\end{array}$ & 69 & $\begin{array}{c}42, \\
9\end{array}$ & 161 & 100 & $($ Lambda) & $(C h i)$ & 0,356 \\
\hline Kurang & 49 & $\begin{array}{c}53, \\
3\end{array}$ & 43 & $\begin{array}{c}46, \\
7\end{array}$ & 92 & 100 & & & 0,304 \\
\hline Total & 171 & $\begin{array}{c}58, \\
8\end{array}$ & 120 & $\begin{array}{c}41, \\
2\end{array}$ & 291 & 100 & & & \\
\hline
\end{tabular}

Berdasarkan Tabel 3 diperoleh nilai $\mathrm{p}=0,026(\mathrm{p}<0,05)$, artinya terdapat hubungan yang signifikan antara pengetahuan dengan perilaku merokok. Nilai lambda $(\lambda)$ sebesar $-0,138$ menunjukkan korelasi negatif dengan kekuatan korelasi yang sangat lemah. Selain itu, juga diperoleh persamaan regresi dari hubungan kedua variabel seperti berikut:

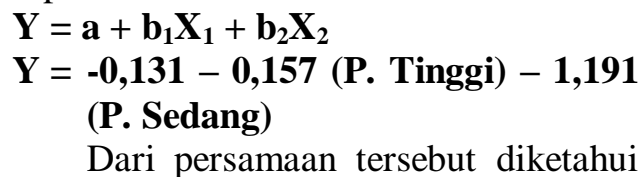

(Y) merupakan perilaku merokok, (a) merupakan konstanta dan $\left(b_{1}\right)$ merupakan koefisien dari pengetahuan tinggi $\left(\mathrm{X}_{1}\right)$ dan $\left(\mathrm{b}_{2}\right)$ merupakan koefisien dari pengetahuan sedang $\left(\mathrm{X}_{2}\right)$. Dari persamaan tersebut dapat diketahui, jika pelajar dengan pengetahuan tinggi nilai $\left(\mathrm{X}_{1}\right)$ adalah (0) dan nilai $\left(\mathrm{X}_{2}\right)$ adalah (1) maka nilai (Y) sebesar -1,322 sehingga, pelajar dengan pengetahuan tinggi memiliki probabilitas sebesar $21,04 \%$ untuk berperilaku merokok. Jika pelajar dengan pengetahuan sedang nilai $\left(\mathrm{X}_{1}\right)$ adalah (1) dan nilai $\left(\mathrm{X}_{2}\right)$ adalah (0) maka nilai $(\mathrm{Y})$ sebesar $-0,288$ sehingga, pelajar dengan pengetahuan sedang 
memiliki probabilitas sebesar $42,84 \%$ untuk berperilaku merokok. Sedangkan, jika pelajar dengan pengetahuan kurang nilai $\left(\mathrm{X}_{1}\right)$ adalah $(0)$ dan nilai $\left(\mathrm{X}_{2}\right)$ adalah (0) maka nilai (Y) sebesar $-0,131$ sehingga, pelajar dengan pengetahuan kurang memiliki probabilitas sebesar $46,72 \%$ untuk berperilaku merokok.

Tabel 4 Hubungan Sikap terhadap Rokok dengan Perilaku Merokok

\begin{tabular}{|c|c|c|c|c|c|c|c|c|c|}
\hline \multirow{3}{*}{$\begin{array}{l}\text { Sikap } \\
\text { Terhadap } \\
\text { Rokok }\end{array}$} & \multicolumn{4}{|c|}{ Perilaku Merokok } & \multirow{2}{*}{\multicolumn{2}{|c|}{ Total }} & \multirow{3}{*}{ Nilai C } & \multirow{3}{*}{ Nilai $p$} & \multirow[b]{2}{*}{$\begin{array}{c}\text { Nilai } \\
\text { OR }\end{array}$} \\
\hline & \multicolumn{2}{|c|}{$\begin{array}{c}\text { Bukan } \\
\text { Perokok }\end{array}$} & \multicolumn{2}{|c|}{ Perokok } & & & & & \\
\hline & $\mathrm{n}$ & $\%$ & $\mathrm{n}$ & $\%$ & $\mathrm{n}$ & $\%$ & & & \\
\hline Tidak & 148 & 76 , & 46 & 23 , & 194 & 100 & & & \\
\hline Mendukung & & 3 & & 7 & & & 0,450 & 0,000 & 0,097 \\
\hline Mendukung & 23 & $\begin{array}{c}23 \\
7\end{array}$ & 74 & $\begin{array}{c}76, \\
3\end{array}$ & 97 & 100 & $(C C)$ & (Chi) & \\
\hline Total & 171 & $\begin{array}{c}58, \\
8\end{array}$ & 120 & $\begin{array}{c}41, \\
2\end{array}$ & 291 & 100 & & & \\
\hline
\end{tabular}

Berdasarkan Tabel 4 diperoleh nilai $\mathrm{p}=0,000(\mathrm{p}<0,05)$, artinya terdapat hubungan yang signifikan antara sikap dengan perilaku merokok. Nilai koefisien kontingensi $(\mathrm{C})$ sebesar 0,450 menunjukkan korelasi positif dengan kekuatan korelasi yang sedang. Selain itu, juga diperoleh persamaan regresi dari hubungan kedua variabel seperti berikut:

$\mathbf{Y}=\mathbf{a}+\mathbf{b} \mathbf{X}_{1}$

$Y=1,169-2,337$ (Sikap)

Dari persamaan tersebut diketahui (Y) merupakan perilaku merokok, (a) merupakan konstanta dan (b) merupakan koefisien dari sikap $\left(\mathrm{X}_{1}\right)$. Dari persamaan dapat diketahui, pelajar dengan sikap setuju terhadap rokok nilai $\left(\mathrm{X}_{1}\right)$ adalah (0) maka nilai $(\mathrm{Y})$ sebesar 1,169 sehingga, pelajar dengan sikap setuju terhadap rokok memiliki probabilitas sebesar 76,29\% untuk berperilaku merokok. Sedangkan, jika pelajar dengan sikap tidak setuju terhadap rokok nilai $\left(\mathrm{X}_{1}\right)$ adalah (1) maka nilai (Y) sebesar -1,168 sehingga, pelajar dengan sikap tidak setuju terhadap rokok memiliki probabilitas sebesar 23,72\% untuk berperilaku merokok.

Tabel 5 Hubungan Uang Saku dengan Perilaku Merokok Pelajar

\begin{tabular}{|c|c|c|c|c|c|c|c|c|c|}
\hline \multirow[t]{3}{*}{ Uang Saku } & \multicolumn{4}{|c|}{ Perilaku Merokok } & \multirow{2}{*}{\multicolumn{2}{|c|}{ Total }} & \multirow[t]{2}{*}{ Nilai C } & \multirow[t]{2}{*}{ Nilai $p$} & \multirow[t]{2}{*}{ Nilai OR } \\
\hline & \multicolumn{2}{|c|}{$\begin{array}{c}\text { Bukan } \\
\text { Perokok }\end{array}$} & \multicolumn{2}{|c|}{ Perokok } & & & & & \\
\hline & $\mathrm{n}$ & $\%$ & $\mathrm{n}$ & $\%$ & $\mathrm{n}$ & $\%$ & 0,323 & 0,000 & \\
\hline Rendah & 89 & $\begin{array}{c}80, \\
2\end{array}$ & 22 & $\begin{array}{c}19, \\
8\end{array}$ & 111 & 100 & $(C C)$ & (Chi) & \\
\hline Tinggi & 82 & $\begin{array}{c}45, \\
6 \\
\end{array}$ & 98 & $\begin{array}{c}54, \\
4\end{array}$ & 180 & 100 & & & 4,835 \\
\hline Total & 171 & $\begin{array}{c}58, \\
8\end{array}$ & 120 & $\begin{array}{c}41, \\
2\end{array}$ & 291 & 100 & & & \\
\hline
\end{tabular}


Berdasarkan Tabel 5 diperoleh nilai $\mathrm{p}=0,000$ ( $\mathrm{p}<$ $0,05)$, artinya terdapat hubungan yang signifikan antara uang saku dengan perilaku merokok. Nilai koefisien kontingensi (C) sebesar 0,323 menunjukkan korelasi positif dengan kekuatan korelasi yang lemah. Selain itu, juga diperoleh persamaan regresi dari hubungan kedua variabel seperti berikut:

$\mathbf{Y}=\mathbf{a}+\mathbf{b} \mathbf{X}_{1}$

$Y=0,178-1,576($ Sikap $)$
Dari persamaan tersebut dapat diketahui, jika pelajar dengan uang saku tinggi nilai $\left(\mathrm{X}_{1}\right)$ adalah (0) maka nilai (Y) sebesar 0,178 sehingga, pelajar dengan uang saku tinggi memiliki probabilitas sebesar 54,43\% untuk berperilaku merokok. Sedangkan, jika pelajar dengan uang saku rendah nilai $\left(\mathrm{X}_{1}\right)$ adalah (1) maka nilai (Y) sebesar -1,398 sehingga, pelajar dengan uang saku rendah memiliki probabilitas sebesar $19,81 \%$ untuk berperilaku merokok.

Tabel 6 Hubungan Status Merokok Anggota Keluarga dengan Perilaku Merokok Pelajar

\begin{tabular}{|c|c|c|c|c|c|c|c|c|c|}
\hline \multirow{3}{*}{$\begin{array}{c}\text { Status } \\
\text { Merokok } \\
\text { Anggota } \\
\text { Keluarga }\end{array}$} & \multicolumn{4}{|c|}{ Perilaku Merokok } & \multicolumn{2}{|c|}{ Total } & \multirow[t]{2}{*}{ Nilai C } & \multirow[t]{2}{*}{ Nilai $p$} & \multirow[t]{2}{*}{ Nilai OR } \\
\hline & \multicolumn{2}{|c|}{$\begin{array}{c}\text { Bukan } \\
\text { Perokok }\end{array}$} & \multicolumn{2}{|c|}{ Perokok } & & & & & \\
\hline & $\mathrm{n}$ & $\%$ & $\mathrm{n}$ & $\%$ & $\mathrm{n}$ & $\%$ & 0,303 & 0,000 & \\
\hline Tidak Ada & 64 & $\begin{array}{c}85, \\
3\end{array}$ & 11 & $\begin{array}{c}14, \\
7\end{array}$ & 75 & 100 & $(C C)$ & (Chi) & \\
\hline Ada & 107 & $\begin{array}{c}49, \\
5\end{array}$ & 109 & $\begin{array}{c}50, \\
5\end{array}$ & 216 & 100 & & & 0,169 \\
\hline Total & 171 & $\begin{array}{c}58, \\
8\end{array}$ & 120 & $\begin{array}{c}41, \\
2\end{array}$ & 291 & 100 & & & \\
\hline
\end{tabular}

Berdasarkan Tabel 6 diperoleh nilai $\mathrm{p}=0,000(\mathrm{p}<$ $0,05)$, artinya terdapat hubungan yang signifikan antara uang saku dengan perilaku merokok. Nilai koefisien kontingensi (C) sebesar 0,303 menunjukkan korelasi positif dengan kekuatan korelasi yang lemah Selain itu, juga diperoleh persamaan regresi dari hubungan kedua variabel seperti berikut:

$\mathbf{Y}=\mathbf{a}+\mathbf{b} \mathbf{X}_{\mathbf{1}}$

\section{$\mathrm{Y}=\mathbf{0 , 0 1 9} \quad-\quad \mathbf{1 , 7 8 0} \quad$ (Status Merokok Anggota \\ Keluarga)}

Dari persamaan tersebut dapat diketahui, jika pelajar dengan terdapat anggota keluarga yang berstatus merokok nilai $\left(\mathrm{X}_{1}\right)$ adalah (0) maka nilai (Y) sebesar
0,019 sehingga, pelajar dengan terdapat anggota keluarga yang berstatus merokok memiliki probabilitas sebesar 50,47\% untuk berperilaku merokok. Sedangkan, jika pelajar dengan tidak terdapat anggota keluarga yang berstatus merokok nilai $\left(\mathrm{X}_{1}\right)$ adalah (1) maka nilai (Y) sebesar -1,761 sehingga, pelajar dengan tidak terdapat anggota keluarga yang berstatus me-rokok memiliki probabilitas sebesar $14,66 \%$ untuk berperilaku merokok.

\section{Analisis Multivariat}

Pada analisis multivariat ini dicari variabel yang berpengaruh terhadap variabel perilaku merokok responden menggunakan regresi logistik dikotom. Variabel yang dihubungkan secara 
bersamaan adalah jenis kelamin, pengetahuan, sikap, uang saku, dan status merokok anggota

keluarga.

Tabel 7 Seleksi Variabel Berdasarkan Nilai p

\begin{tabular}{llccc}
\hline No & \multicolumn{1}{c}{ Variabel } & P Value & Exp (B) & Koefisien \\
\hline 1 & Jenis Kelamin (1) & 0,000 & 0,037 & $-3,304$ \\
2 & Pengetahuan & 0,161 & & \\
& Pengetahuan (1) & 0,461 & 0,651 & $-0,429$ \\
& Pengetahuan (2) & 0,328 & 1,469 & 0,385 \\
3 & Sikap (1) & 0,000 & 0,072 & $-2,635$ \\
4 & Uang Saku (1) & 0,000 & 0,243 & $-1,413$ \\
5 & Statu Merokok Anggota & 0,000 & 0,088 & $-2,429$ \\
& Keluarga (1) & & & \\
& Konstanta & & & 2,459 \\
\hline
\end{tabular}

Dari hasil analisis diketahui variabel pengetahuan memiliki nilai $\mathrm{p}>0,05$ sehingga dikeluarkan terlebih dahulu. Variabel lain yaitu jenis kelamin, sikap, uang saku, dan status merokok anggota keluarga memiliki nilai $\mathrm{p}<0,05$ sehingga tetap masuk dalam pemodelan. Pemodelan regresi logistik tanpa variabel pengetahuan dapat dilihat pada Tabel

Tabel 8 Hasil Pemodelan Multivariat Regresi Logistik Dikotom

\begin{tabular}{llccc}
\hline No & \multicolumn{1}{c}{ Variabel } & P Value & Exp (B) & Koefisien \\
\hline 1 & Jenis Kelamin (1) & 0,000 & 0,034 & $-3,383$ \\
\hline 2 & Sikap (1) & 0,000 & 0,079 & $-2,544$ \\
\hline 3 & Uang Saku (1) & 0,000 & 0,220 & $-1,512$ \\
\hline 4 & $\begin{array}{l}\text { Statu Merokok Anggota } \\
\text { Keluarga (1) }\end{array}$ & 0,000 & 0,093 & $-2,378$ \\
\hline & & & \\
\hline Konstanta & & & 2,598 \\
\hline
\end{tabular}

Berdasarkan Tabel 8 diketahui bahwa tidak terjadi perubahan Odds Ratio (Exp (B)) sebesar > $10 \%$ sehingga pemodelan telah selesai dengan tanpa variabel pengetahuan pada pemodelan. Variabel yang berpengaruh terhadap perilaku merokok pelajar adalah jenis kelamin, sikap, uang saku dan status merokok anggota keluarga. Kekuatan hubungan dilihat dari nilai Odds Ratio (Exp (B)) dimana kekuatan hubungan terbesar adalah uang pelajar (OR saku $=0,220$ ) dan kekuatan hubungan terkecil adalah jenis kelamin $(\mathrm{OR}=0,034)$.

Diketahui pula, konstanta dan koefisien masing-masing variabel sehingga dapat diaplikasikan dengan rumus regresi logistik. Aplikasi dari rumus tersebut adalah sebagai berikut.

$$
\mathbf{Y}=\mathbf{a}+\mathbf{b}_{1} \mathbf{X}_{1}+\mathbf{b}_{2} \mathbf{X}_{2}+\mathbf{b}_{1} \mathbf{X}_{1}+
$$
$\mathbf{b}_{2} \mathbf{X}_{2}$
$\mathrm{Y}=\mathbf{2 , 5 9 8}$ 3,383(Jenis Kelamin) - 2,544(Sikap) 1,512(Uang Saku) 2,598(Status Merokok Anggota Keluarga)

Perilaku merokok pelajar (Y) dapat diprediksi dengan menghitung konstanta (a) dan koefisien (b) dari masing-masing variabel. Konstanta diketahui sebesar 2,598. Sedangkan, koefisien dari jenis kelamin sebesar -3,383, sikap sebesar - 
2,544, uang saku sebesar -1,512, dan status merokok anggota keluarga sebesar -2,378. Nilai variabel bebas diisi dengan nilai (0) untuk skala yang beresiko terhadap perilaku merokok dan (1) untuk skala yang tidak beresiko terhadap perilaku merokok. Contohnya, diketahui terdapat pelajar dengan jenis kelamin lakilaki $(\mathrm{O})$, bersikap mendukung terhadap rokok (0), memiliki uang saku tinggi (0), dan terdapat anggota keluarga dengan status sebagai perokok (0). Didapat pemodelan sebagai berikut.

$\mathrm{Y}=2,598-3,383 \times(0)-2,544 \mathrm{x}$

(0) $-1,512 \times(0)-2,598 \times$

(0)

$\mathrm{Y}=2,598-0-0-0-0$

$\mathrm{Y}=2,598$

Setalah diketahui nilai (Y) maka dicari probabilitasnya dengan rumus:

$\mathbf{P}=\mathbf{1} /(\mathbf{1}+\exp (-\mathbf{Y}))$

$\mathrm{P}=1 /(1+\exp (-2,598))$

$\mathrm{P}=1 /(1,0744)$

$\mathrm{P}=0,9307$

$\mathrm{P}=93,07 \%$

Berdasarkan perhitungan, pelajar dengan dengan jenis kelamin laki-laki, bersikap mendukung terhadap rokok, memiliki uang saku tinggi, dan terdapat anggota keluarga dengan status sebagai perokok, me-miliki probabilitas sebesar 93,07\% untuk berperilaku merokok. Sebaliknya, pelajar dengan jenis kelamin perempuan, bersikap tidak mendu-kung terhadap rokok, memiliki uang saku rendah, dan tidak terdapat anggota keluarga dengan status sebagai perokok memiliki proba-bilitas sebesar $0,78 \%$ untuk berpe-rilaku merokok

\section{PEMBAHASAN}

\section{Perilaku Merokok Responden}

Hasil penelitian yang dilakukan pada 291 responden di SMKN 2 Kota Probolinggo tahun
2017 menunjukkan bahwa proporsi pelajar yang merokok adalah sebanyak 120 pelajar $(41,2 \%)$, lebih kecil dibandingkan pelajar yang tidak merokok yaitu sebanyak 171 pelajar (58\%). Berdasarkan penelitian Litbang Kemenkes (2015) terhadap 11.163 pelajar di Indonesia diketahui bahwa pelajar yang merokok lebih sedikit dari pada pelajar yang tidak merokok yaitu sebesar 11,6\%. Menurut Bringham (dalam Maseda dkk, 2013:4), perilaku merokok pada remaja meru-pakan suatu simbolisasi yaitu simbol kematangan, kekuatan, kepemimpinan dan daya tarik terhadap lawan jenis.

Berdasarkan hasil penelitian dite-mukan perbedaan intensitas merokok tiap hari. Sebanyak 117 pelajar meru-pakan perokok ringan $(97,5 \%), 3$ pelajar merupakan perokok sedang $(2,5 \%)$, dan tidak terdapat perokok dengan kategori perokok berat. Hal ini berarti jumlah pelajar dengan status perokok ringan lebih banyak dibandingkan dengan perokok sedang dan berat. Data Ris-kesdas (2010) juga menunjukkan bahwa secara nasional perokok perokok ringan lebih banyak dari pada perokok sedang ataupun perokok berat. Perokok ringan di Indonesia diketahui sebesar $52,3 \%$ dan perokok sedang sebesar $20 \%$ dari keseluruhan jumlah perokok di Indonesia (Riskesdas, 2010:XI).

Berkaitan dengan usia merokok, perokok remaja Indonesia yaitu kelompok umur 15-24 tahun merupakan kelompok pengkonsumsi rokok paling rendah jika di bandingkan kelompok umur yang lain (Kemenkes, 2011). Namun, data Kementerian Kesehatan menunjukkan, prevalensi merokok remaja usia 16-19 tahun 
meningkat 3 kali lipat dari 7,1\% di tahun 1995 menjadi 20,5\% pada tahun 2014 (Kemenkes, 2016). Setyoadi (dalam Chotidjah, 2011) menyatakan, Indonesia merupakan negara yang me-miliki jumlah perokok remaja terbanyak di dunia dimana sekitar $80 \%$.

Berdasarkan hasil penelitian, juga diketahui jenis rokok yang dikonsumsi oleh pelajar. Sebanyak 111 pelajar (92.5\%) mengaku mengkonsumsi rokok dengan menggunakan filter sedangkan 9 pelajar $(7,5 \%)$ mengaku mengkonsumsi rokok tanpa menggunakan filter. Filter rokok sendiri terbuat dari bahan busa serabut sintetis yang berguna menyaring nikotin dan tar (Sukmana, 2011). Perokok yang biasa mengkonsumsi rokok tidak berfilter beresiko mangalami hipertensi 3,518 kali dibanding perokok yang biasa mengkonsumsi rokok berfilter dikarenakan potensi masuknya nikotin dan tar dalam paru-paru lebih besar pada rokok yang tidak menggu-nakan filter (Eirmawati, 2014).

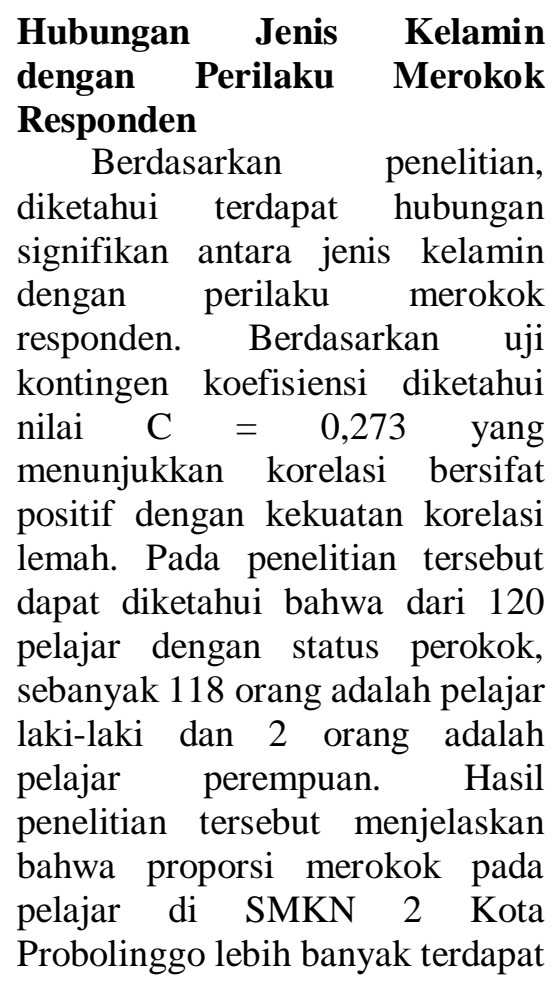

pada laki-laki dari pada perempuan.

Penelitian Lindawati (2012) juga menunjukkan hasil yang sama, yaitu proporsi yang lebih besar pada laki-laki terkai perilaku merokok dibandingkan perempuan. Penelitian Lindawati menunjukkan terdapat hubungan yang signifikan antara variabel perilaku merokok dengan jenis kelamin (Lindawati, 2012). Hasil survei WHO (2015) terhadap pelajar SMP dan SMA di 26 Provinsi di Indonesia menunjukkan bahwa pelajar laki-laki lebih banyak memiliki perilaku beresiko terkait merokok yaitu $22 \%$ pada laki-laki dan 1,6\% pada perempuan.

Menurut WHO (dalam Lindawati, 2012), dalam pengambilan keputusan yang beresiko, laki-laki memiliki perilaku yang lebih berani dari pada perempuan termasuk dalam hal yang berkaitan dengan kesehatan seperti konsumsi alkohol dan meroko (dalam Reimondos, 2012) menyatakan bahwa merokok bagi laki-laki diterima sebagai perilaku yang normal, bahkan dianggap sebagai simbol kejantanan. Selain itu faktor budaya juga terhadap perilaku merokok. Menurut Barraclough (dalam Reimondos, 2012) merokok bagi perempuan pada banyak daerah di Indonesia dianggap sebagai bentuk penyimpangan sementara, perilaku merokok pada laki-laki dapat diterima oleh masyarakat sebagai hal yang biasa.

\section{Hubungan Pengetahuan Tentang Rokok dengan Perilaku Merokok Responden Berdasarkan penelitian, diketahui terdapat hubungan signifikan antara pengetahuan tentang rokok dengan perilaku merokok. Berdasarkan uji lambda diketahui nilai $\lambda=-0,138$ yang}


menunjukkan korelasi bersifat negatif dengan kekuatan korelasi sangat lemah. Dari hasil penelitian dapat diketahui 117 responden berstatus sebagai perokok terbagi menjadi pelajar dengan pengetahuan kurang tentang rokok sebanyak 43 orang, pelajar dengan pengetahuan sedang tentang rokok sebanyak 69 orang dan pelajar dengan pengetahuan tinggi tentang rokok sebanyak 8 orang. Hasil penelitian tersebut menjelaskan bahwa proporsi merokok pada pelajar di SMKN 2 Kota Probolinggo lebih banyak terdapat pada pelajar dengan pengetahuan kurang dari pada pelajar dengan pengetahuan tinggi.

Penelitian Namakin (2005) juga memperlihatkan hasil yang sama yaitu terdapat hubungan yang signifikan antara pengetahuan tentang rokok dengan prevalensi merokok pelajar menengah atas di Birjand Iran. Hasil ini juga didukung oleh penelitian Maseda (2013) pada remaja di SMA Negeri Tompasobaru menunjukkan bahwa pengetahuan tentang bahaya rokok memiliki hubungan yang signifikan dengan perilaku merokok remaja. Namun, pada penelitian lain ditemukan hasil berbeda yang menunjukkan bahwa pengetahuan mengenai rokok tidak memiliki hubungan terhadap rokok. Pene-litian yang dilakukan Rahmadi (2013) menunjukkan bahwa tidak terdapat hubungan yang bermakna antara pengetahuan terhadap kebiasaan merokok pada siswa SMP di Kota Padang.

Pengetahuan merupakan aspek penghubung yang mendukung terciptanya sebuah perilaku dalam hal ini antara pengetahuan tentang rokok dengan perilaku merokok seseorang. Menurut Chotidjah (2012), pengetahuan atau informasi seseorang tentang rokok akan meningkatkan kontrol dirinya (perilaku) pada masalah kesehatan (perilaku merokok). Rice \& Dolgin (dalam Chotidjah, 2012) mengemukakan bahwa pengetahuan tentang kesehatan dari perilaku tertentu berkaitan terhadap keputusan perilaku kesehatan pada remaja disamping terdapat faktor-faktor komplek lain yang mempengaruhi perilaku kesehatan tersebut.

Pada analisis regresi logistik pene-litian ini diketahui bahwa pengetahuan tentang rokok tidak menjadi prediktor pada pemodelan regresi logistik. Selain itu, pada analisis korelasi diketahui bahwa hubungan antara pengetahuan tentang rokok dengan perilaku merokok pelajar bersifat lemah. Padahal, menurut Sunaryo (2014), perilaku yang didasari pengetahuan umumnya berlangsung lama. Namun, pada kenyataannya terjadi berbagai variasi pada hasil penelitian dimana pelajar dengan pengetahuan tinggi juga berperilaku merokok. Hal ini menurut Bringham (dalam Maseda dkk, 2013) dijelaskan bahwa alasan yang melatar belakangi remaja dalam berperilaku merokok simbolisasi yaitu simbol kematangan, kekuatan, kepe-mimpinan, dan daya tarik terhadap lawan jenis sehingga aspek pengetahuan sebagai faktor menjadi lemah dalam hubungannya dengan perilaku merokok.

\section{Hubungan Sikap terhadap Rokok dengan Perilaku Merokok Responden \\ Berdasarkan penelitian,} diketahui terdapat hubungan yang signifikan antara sikap dengan perilaku merokok responden. Berdasarkan uji kontingen koefisiensi diketahui nilai $\mathrm{C}=$ 
0,450 yang menunjukkan korelasi bersifat positif dengan kekuatan korelasi moderat. Dari 120 pelajar yang berstatus perokok, sebanyak 46 responden memi-liki sikap tidak mendukung perilaku merokok dan 74 responden memiliki sikap mendukung perilaku merokok. Selain itu, dari 171 pelajar dengan status bukan perokok, 148 pelajar diantaranya memiliki sikap tidak mendukung peri-laku merokok dan 23 pelajar memiliki sikap mendukung terhadap rokok.

Hasil ini didukung dengan pene-litian Maseda (2013) dimana terdapat hubungan yang signifikan antara sikap terhadap rokok dengan perilaku merokok responden. Dari 91 responden dengan sikap positif sebanyak 22 orang berperilaku merokok dan 69 orang berperilaku tidak merokok, sedangkan dari 37 responden dengan sikap negatif terdapat 30 orang yang berperilaku merokok dan 7 orang tidak merokok (Maseda, 2013). Berkaitan dengan perilaku merokok, Sarwono (dalam Aryani, 2013) menyebutkan bahwa sikap merupakan hal yang sangat penting terhadap perilaku merokok seseorang, karena pada hakikatnya sikap akan menentukan seseorang berperilaku terhadap sesuatu objek baik yang disadari atau tidak disadari.

Berdasarkan pengamatan terhadap jawaban resnpoden, terdapat satu penya-taan (nomor 19) dimana banyak responden (142 orang) memberikan sikap yang positif (setuju atau mendukung) terhadap perilaku merokok, yaitu "Merokok merupakan hak asai manusia sehingga siapapun bebas merokok kapan saja dan dimana saja". Jika dikaitkan dengan teori Dariyo (2008) berkaitan dengan tiga kom-ponen sikap dalam membentuk perilaku, pernyataan tersebut termasuk dalam behavioral component, yaitu sejauh mana indivudu merespon apa yang diketahuinya dalam bentuk komitmen, artinya seseorang akan berperilaku sesuai dengan komitmennya. Maka dapat disimpulkan bahwa behavioral component responden merupakan alasan yang paling banyak dipilih responden dalam bersikap positif (setuju atau mendukung) terhadap perilaku merokok.

\section{Hubungan Uang Saku dengan Perilaku Merokok Responden} Berdasarkan penelitian, diketahui terdapat hubungan yang signifikan antara uang saku dengan perilaku merokok pelajar. Berdasarkan uji kontingen koefisiensi diketahui nilai $\mathrm{C}=$ 0,323 yang menunjukkan korelasi bersifat positif dengan kekuatan korelasi lemah. Dari 120 responden yang berstatus sebagai perokok diketahui bahwa rata-rata uang saku yang dibawa responden setiap harinya adalah Rp9.500,00. Dari jumlah sampel tersebut, 98 pelajar diantaranya memiliki uang saku yang tinggi dan 22 pelajar memiliki besaran uang saku yang rendah. Selain itu, terdapat 171 pelajar yang memiliki status bukan perokok dimana 82 pelajar diantaranya memiliki besaran uang saku yang tinggi dan 89 pelajar memiliki uang saku yang rendah.

Ramantika (2014) dalam penelitiannya menyatakan bahwa terdapat hubungan positif antara besar uang saku yang dimiliki pelajar terhadap perilaku merokok pelajar. Shaluhiyah, Karyono dan Noor (2006) dalam penelitiannya juga membuktikan bahwa pada pelajar dengan uang saku Rp2.100,00 ke atas tergolong dalam kategori merokok tinggi 
mencapai $32,95 \%$, sedangkan pelajar dengan uang saku Rp2.100,00 ke bawah dikategorikan praktik merokok rendah sebanyak 67,05\%. Namun menurut Mc Donal (dalam Lindawati, 2012), penghasilan keluarga yang rendah atau kemiskinan membuat remaja cemas dan depresi sehingga, keluarga dengan berpenghasilan rendah (uang jajan rendah) lima kali lebih sulit untuk meninggalkan tembakau, dibandingkan dengan keluarga sejahtera (uang jajan besar).

Harga rokok di Indonesia sangat terjangkau bagi remaja bahkan anak-anak. Sebagai contoh, di Australia harga sebungkus rokok adalah Rp170.000,00 (AIPHSS, 2014). Remaja atau anak-anak sulit mendapatkan rokok baik dari segi harga yang cukup tinggi dan kemudahan untuk mendapatkannya. Dibandingkan dengan di Indonesia dimana harga sebungkus rokok sekitar Rp12.000,00. Di Indonesia, rokok mudah didapat baik dari segi harga, ketersediaan maupun aksesnya. Menurut survei GYTS 2009 (IAKMI, 2012) sebesar 59\% remaja muda usia sekolah di Indonesia yang berstatus sebagai perokok membeli secara bebas rokok di toko tanpa penolakan dari penjual.

\section{Hubungan Status Perokok Anggota Keluarga dengan Perilaku Merokok Responden}

Berdasarkan penelitian, terdapat hubungan yang signifikan antara status merokok anggota keluarga dengan perilaku merokok responden. Berdasar-kan uji kontingen koefisiensi diketahui nilai $\mathrm{C}=0,303$ yang menunjukkan korelasi bersifat positif dengan kekuatan korelasi lemah. Dari 120 pelajar yang berstatus merokok, terdapat 109 pelajar diantaranya memiliki anggota keluarga dengan status perokok dan 11 pelajar memiliki anggota keluarga dengan status bukan perokok.

Perilaku merokok orang tua merupakan salah satu faktor terbentuknya perilaku merokok pada remaja (Rahmadi, 2013). Kustanti (2014) menyebutkan bahwa keluarga memiliki pengaruh yang sangat kuat terhadap perilaku remaja, jika orang tua merokok, maka sangat mungkin akan diikuti anaknya. Berdasarkan penelitian Chotidjah (2012) ditemukan bahwa sebagian besar perokok remaja pertama mengenal rokok dari orangtua, keluarga dan teman sebaya. Penelitian yang dilakukan Kustanti (2014) juga menyebutkan bahwa terdapat hubungan antara pengaruh keluarga dengan perilaku merokok pada siswa laki-laki SMPN 1 Slogohimo Wonogiri.

Penelitian yang dilakukan Vivaldi (2008) juga menunjukkan hasil yang sama walaupun terdapat perbedaan indikator. Pada penelitian yang dilaku-kan Vivaldi (2008) membagi status merokok orang tua menjadi tiga yaitu perokok, bekas perokok, dan bukan perokok sedangkan, perilaku merokok responden dibagi menjadi ringan, sedang, kuat, dan sangat kuat. Hasil analisis didapatkan nilai $\mathrm{p}=0,035$ yang berarti terdapat korelasi yang bermakna antara status merokok orang tua dengan perilaku merokok responden dengan status perokok orang tua dengan kategori perokok didominasi perilaku merokok responden dengan kategori kuat sebanyak 21 responden (Vivaldi, 2008).

Bandura dan Walter (dalam Notoatmodjo, 2003) mengemukakan bahwa orang tua merupakan salah contoh atau model dimana anak akan 
mempelajari hal yang dilakukan dan cenderung melakukan hal yang sama dengan apa yang dilakukan oleh modelnya. Orang tua merupakan contoh dan model bagi remaja, sehingga ketika orang tua berperilaku buruk maka secara tidak langsung mereka telah mengajar-kan perilaku buruk (Vivaldi, 2016). Menurut Husnaini (2007:28), keluarga khususnya orang tua memiliki peranan yang sangat besar dalam membentuk perilaku merokok dalam diri tiap anggotanya, yaitu anak-anak remaja menjadi terbiasa merokok karena mengikuti kebiasaan orang tuanya dimana secara tidak langsung orang tua telah mengajarkan perilaku merokok. Menurut Kementerian Kesehatan (2011), diperkirakan lebih dari 40,3 juta anak tinggal bersama perokok dan terpapar asap rokok di lingkungannya.

\section{KESIMPULAN}

Perilaku pelajar di SMKN 2 Kota Probolinggo masih cukup tinggi. Berda-sarkan hasil penelitian terhadap 291 responden diketahui sebesar 58\% pelajar tidak merokok dan sebesar $41,2 \%$ pelajar dengan status perokok. Pelajar dengan status merokok terbagi menjadi perokok ringan dan sedang yaitu dari 120 pelajar dengan status perokok, 97,5\% diantaranya adalah perokok ringan dan 2,5\% merupakan perokok sedang. Berdasarkan hasil analisis hubungan, diketahui hubungan faktor predisposisi, pemungkin dan penguat dengan perilaku merokok pelajar SMKN 2 Kota Probolinggo tahun 2017 adalah sebagai berikut.

1. Terdapat hubungan yang signifikan antara jenis kelamin dengan perilaku merokok pelajar. Laki-laki lebih berani dalam meng- ambil resiko terkait kesehatan dalam hal ini perilaku merokok. Disamping itu dari sisi budaya, merokok di kalangan wanita masih menjadi hal yang tabu di masyarakat.

2. Terdapat hubungan signifikan antara pengetahuan tentang rokok dengan perilaku merokok pelajar. Pengetahuan merupakan aspek penghubung antara pusat kendali kesehatan dan perilaku seseorang dalam hal ini perilaku merokok.

3. Terdapat hubungan yang signifikan sikap terhadap rokok dengan perilaku merokok pelajar. Sikap merupakan hal yang sangat penting terhadap perilaku merokok seseorang, karena pada hakikatnya sikap akan menentukan seseorang ber-perilaku terhadap sesuatu objek baik negatif atau positif.

4. Terdapat hubungan yang signifikan antara besaran uang saku dengan perilaku merokok pelajar. Ketersediaan uang untuk membeli rokok juga didukung dengan kemudahan pelajar dalam mendapatkan rokok.

5. Terdapat hubungan yang signifikan antara status perokok anggota keluarga dengan perilaku merokok responden. Keluarga memiliki peranan yang penting dalam membentuk perilaku merokok dalam diri anak-anaknya (remaja) untuk menjadi terbiasa merokok karena mengikuti kebiasaan orang tuanya.

6. Berdasarkan analisis diketahui variabel yang paling berpengaruh terhadap perilaku merokok pelajar adalah jenis kelamin, sikap terhadap rokok, uang saku dan status merokok anggota 
keluarga. Variabel pengetahuan tidak termasuk yang berpengaruh karena perilaku merokok dikalangan remaja tidak hanya dipengaruhi oleh pengetahuan. Perilaku merokok pada remaja merupakan bentuk simbolisasi kematangan dan daya tarik lawan jenis.

\section{SARAN}

Prevalensi merokok pada kalangan remaja terus meningkat setiap tahunnya. Untuk mencegah peningkatan jumlah prevalensi merokok pada remaja khususnya dikalangan pelajar perlu penanganan dengan melibatkan semua komponen.

\section{Pemerintah atau Dinas Keseha-tan Kota Probolinggo \\ Dinas Kesehatan Kota} Probolinggo diharapkan mampu menciptakan kondisi lingkungan yang bebas dari asap rokok sesuai dengan pedoman Kawasan Tanpa Rokok (KTR) yaitu Permenkes Nomor 188/Mnkes/PB/2011. Salah satu caranya adalah mengkampanyekan larangan merokok di dalam rumah bagi setiap warga baik secara langsung ataupun melalui media promosi sebagai upaya menjadikan orang tua contoh atau model untuk anakanaknya (remaja) untuk tidak berperilaku merokok.

2. Dinas Pendidikan Kota Probolinggo

Salah satu faktor bagi pelajar untuk berperilaku adalah ketersediaan informasi. Berkaitan dengan terus meningkatnya prevalensi merokok pada pelajar, Dinas Pendidikan Kota Probolinggo diharapkan mampu memberi informasi atau pengetahuan terkait bahaya rokok dalam hal ini dapat menggunakan media internet atau sosial media. Dengan menggunakan media sosial pelajar akan lebih mudah untuk mengakses informasi sehingga diharapkan timbul kesadaran akan bahaya dari perilaku merokok.

\section{SMKN 2 Kota Probolinggo}

Dalam upaya meminimalisir peningkatan prevalensi merokok pada pelajar, SMKN 2 diharapkan mampu menerapkan pengawasan yang ketat terhadap aktifitas merokok, melaksanakan aturan Kawasan Tanpa Rokok dengan baik, meningkatkan pengetahuan pelajar terkait bahaya merokok baik melalui Unit Kesehatan Sekolah (UKS) atau Bimbingan Konseling (BK) dan menutup akses pelajar dari warung-warung diluar sekolah yang menjual rokok.

\section{Bagi Peneliti Selanjutnya}

Faktor lain yang diduga memiliki hubungan dengan perilaku merokok pelajar SMKN 2 Kota Probolinggo adalah pengaruh merokok teman sebaya dan kebijakan tentang rokok di sekolah. Diharapkan peneliti lain mampu melakukan penelitian terkait faktor-faktor tersebut ataupun faktor lain yang berhubungan dengan perilaku merokok pelajar. Selain itu, pengembangan media atau metode dalam meningkatkan kesadaran pelajar terhadap bahaya rokok masih sangat dibutuhkan. Oleh karena itu, bagi pene-liti selanjutnya diharapkan mampu melanjutkan kajian mendalam dan memberi solusi terhadap permasalahan perilaku merokok di SMKN 2 Kota Probolinggo.

\section{DAFTAR RUJUKAN}

Aryani, Maya. 2013. Hubungan Antara Sikap Terhadap Kesehatan Dengan Perilaku Merokok Di SMA Negeri 1 Pleret Bantul. Jurnal Psikologi, (Online), 2 (1): 1 16, (http://id. portalgaruda.org/?ref=brows 
e\&mod=viewarticle \&article $=$

123250), diakses 27

Desember 2016.

Australia Indonesia Partnership

for Health Systems

Strengthening. 2014. Nota Kebijakan AIPHS: Apa Yang Bisa Dilakukan Terhadap Kesehatan Masyarakat, (Online), (http://aiphss.org/id/whatcanbe-done-about-publichealthenemy-1/), diakses 28 Desember 2016.

Azwar, Saifuddin. 2002. Sikap Manusia: Teori dan Pengukurannya. Yogyakarta: Pustaka Pelajar (Cetakan V).

Barreto, Maria Sandhi., dkk. 2011. Contextual Faktors Associated with Smoking Among Brazilian Adolescents. Jurnal Epidemiologi, (Online), (http://search.proquest. com), diakses 12 Juli 2017.

Chotidjah, Siti. 2012. Pengatahuan Tentang Rokok, Pusat Kendali Kesehatan Eksternal Dan Perilaku Merokok. Jurnal Ilmu Pendidikan, (Online), 16 (1): 49-56, (http:// journal.ui.ac.id/index.php/\%2 Ohumanities/article/viewFile/ 1493/1294), diakses 15 September 2016.

Dahlan, M. Sopiyudin. 2015. Statistik Untuk Kedokteran dan Kesehatan: Seri 1 Edisi 6. Jakarta Pusat: Epidemiologi Indonesia (Pstat-Consulting).

Dariyo, Agoes. 2008. Psikologi Perkembangan Dewasa Muda. Jakarta: PT Gramedia Widiasarana Indonesia, (Online), (https://books. google.co.id/books?id=mTR SFNc1VQoC\&pg=PA39\&dq $=$ tipe+perokok\&hl=id\&sa=X \&redir_esc $=\mathrm{y} \# \mathrm{v}=$ onepage $\& \mathrm{q}$ tipe\%20perokok\&f=false), diakses 16 Januari 2017.

Darmawan, Deni. (2013). Metode Penelitian Kuantitatif. Bandung: PT Remaja Rosdakarya.

Dinas Kesehatan Kota Probolinggo. 2015. Profil Kesehatan 2015, (Online), (http://www.depkes.go id/ resources/download/profil/P ROFIL_KAB_KOTA_2015/ 3574_Jatim_Kota_Proboling go_2015.pdf), diakses 30 Mei 2017.

Eirmawati, Cici., dkk. 2014. Hubungan antara Kebiasaan Merokok dengan Kejadian Hipertensi di RSD dr. Soebandi Jember. Jurnal Kesehatan, (Online), (http://jurnal.

unej.ac.id/index.php/JPK/arti cle/download/198), diakses 10 Juni 2017.

Global Youth Tobacco Survey (GYTS). 2014. Fact Sheet: Indonesia,

(Online),(http://www.search. who.int/tobacco/documents/i no_gyts_report_2014), diakses $16 \quad$ September 2016.

Husaini, Aiman. 2007. Tobat Merokok: Rahasia \& Cara Empatik Berhenti Merokok. Depok: Pustaka IIMaN, (Online), (https: //books.google.co .id/books?id=R021yzR3EPI $\mathrm{C} \& p g=P A 15 \& d q=$ rokok\&hl $=\mathrm{id} \& \mathrm{sa}=\mathrm{X} \&$ redir_esc $=\mathrm{y} \# \mathrm{v}=\mathrm{O}$ nepage $\& \mathrm{q}=$ rokok\& $\mathrm{f}=$ false), diakses 12 Januari 2017.

Ikatan Ahli Kesehatan Masyarakat Indonesia, TCSC. 2012a. Fact Sheet: Industri Rokok di Indonesia, (Online), (http://tcscindonesia.org /wpcontent/uploads/2012/08/ Fact_Sheet_Industri_Rokok_ 
di_Indonesia.pdf), diakses 10 Juli 2017.

Ikatan Ahli Kesehatan Masyarakat Indonesia, TCSC. 2012b. Fact Sheet:Masalah Rokok di Indonesia, (Online), (http://tcsc-indonesia.org /wpcontent/uploads/2012/10/ MasaRokok-diIndonesia.pdf) diakses 23 Mei 2017.

Kementerian Kesehatan Republik Indonesia. 2007. Laporan Nasional Riset Kesehatan Dasar, (Online), (www.kemen kes.go.id), diakses 25 September 2015.

Kementerian Kesehatan Republik Indonesia. 2010. Laporan Nasional Riset Kesehatan Dasar, (Online), (www.kemen kes.go.id), diakses 20 Mei 2017.

Kementerian Kesehatan Republik Indonesia. Pusat Promosi Keseha-tan. 2011. Prototipe Media Kawasan Tanpa Rokok, (Online), (www.kemenkes.go.id), diakses 1 Juli 2017.

Kementerian Kesehatan Republik Indonesia. 2015. InfoDATIN. Perilaku Merokok Masyarakat Indonesia Berdasarkan Riskesdes 2007 dan 2013, (Online), (http: //depkes.go.id), diakses 27 Agustus 2016.

Kementerian Kesehatan Republik Indonesia. 2015b. InfoDATIN Situasi

Reproduksi Kesehatan depkes go id/esources/downl oad/pusdatin/infodatin/infoda tin\%20reproduksi\%20remaja -ed.pdf), diakses 27 Juli 2017.

Kementerian Kesehatan Republik Indonesia. 2016. HTTS 2016: Suarakan Kebenaran Jangan Bunuh Dirimu Dengan
Candu Rokok, (Online), (http://www.

depkes.go.id/article/print/160 60300002/htts-2016suarakan-kebenaran-janganbunuhdirimu-dengancandurokok), diakses 6 Maret 2017.

Komasari, Dian \& Helmi, Alvin Fadilla. 2000. Faktor-faktor Penyebab Perilaku Merokok Pada Remaja. Jurnal Psikologi, 1 (37): 37-47, (Online), (http://avin.staff.ugm.ac. $\mathrm{id} /$ data/jurnal/perilakumerok ok_avin), diakses 10 November 2016.

Kustanti, Astri Ayuk. 2014. Hubungan Aantara Pengaruh Kekuarga, Pengaruh Teman Dan Pengaruh Iklan Terhadap Perilaku Merokok Pada Remaja DI SMP N I Slogohimo Wonogiri. Naskah Publikasi. Surakarta: FIK, (Online),

(http://eprints.ums.ac.id/2861 6/24/NASKAH_PUBLIKAS

I), diakses 22 November 2016.

Lindawati., Miradwiyana, Bara \& Sumiati. 2012. Faktor-Faktor Yang Mempengaruhi Perilaku Merokok SiswaSiswi SMP Di Daerah Jakarta Selatan Tahun 2011. Jurnal Health Quality, (Online), 2 (4): 189-200, (http://poltekkesjakarta1 .ac.id/file/dokumen/741_Lin dawati_200), diakses 1 Januari 2017

Litbang Kemenkes. 2015. FACT SHEET: Perilaku Berisiko Kesehatan pada Pelajar SMP dan SMA di Indonesia, (Online), (www.kemenkes.go.id), diakses 10 Juli 2017.

Maseda, Devita Rosalin., dkk. 2013.

Hubungan 
Pengetahuan dan Sikap Tentang Bahaya Merokok Dengan Perilaku Merokok Pada Remaja Putra Di SMA Negeri I Tompasobaru. Jurnal Keperawat-an, (Online), (https:// ejournal. unsrat.ac.id/index.php/jkp/art icle/view), diakses 12 Juli 2017.

Namakin, K. 2005. Prevalence of Cigarette Smoking and Evaluation of Attitude and Knowladge in its Hight School Boys in Birjand 2005. Jurnal Kesehatan, (Online), (journal. bums.acir), diakses 12 Juli 2017.

Notoatmodjo, Soekidjo. 2003. Pendidikan Dan Perilaku Kesehatan. Jakarta: Rineka Cipta.

Notoatmodjo, Soekidjo. 2011. Ilmu Kesehatan Masyarakat: Ilmu \& Seni. Jakarta: Rineka Cipta.

Peraturan Pemerintah Republik Indonesia No. 109 tahun 2012 tentang Pengamanan Bahan yang Mengandung Zat Adiktif berupa Produk Tembakau bagi Kesehatan. (Online),

(http://sipuu.setkab.go.id /PUUdoc/173643/PP1092012 ), diakses 21 November 2016.

Rahmadi, Afdol. Lestari, Yuniar \& Yenita. 2013. Hubungan Penge-tahuan Dan Sikap Terhadap Rokok Dengan Kebiasaan Merokok Siswa SMP Di Kota Padang. Jurnal Kesehatan, (Online), 2 (1): 25-18,

(http://jurnal.fk.unand.ac.id/i ndex.php/jka/article/view/62) , diakses 30 Desember 2016.

Ramantika, Villy. 2014. FaktorFaktor Yang Mempengaruhi Perilaku Merokok Pada Remaja Usia Pertengahan (15-17 Tahun) Di SMK
Negeri 01 Mempawah Timur.

Naskah Publikasi. Pontianak:

FK,

(Online),

(http://jurnal.untan.ac.id/

index.php/jmkeperawatanFK

/article/view/), diakses 17 Maret 2017.

Reimondos, Anna., dkk. 2012. Policy Background No. 2: Merokok Dan Penduduk Dewasa Muda Di Indonesiai. Canberra, Australia: Australian Demographic and Sosial Reasearch Institute, (Online), (http ://demography.anu.edu.au/sit es/default/files/research/trans ition-to adulthood/PolicyBack ground_\%232_SmokingBhs_Indonesia.pdf), diakses 28 Desember 2016.

Shaluhiyah, Zahroh., Kryono \& Noor, Farid. 2006. FaktorFaktor Yang Berpengaruh Terhadap Praktik Merokok Pada Remaja Sekolah Menengah Pertama Di Kabupaten Kudus Tahun 2005. Jurnal Promosi Kesehatan Indonesia, (online), 1 (1): 1-8, (http://download.portal garuda.org/article.php?article $=21985 \& \mathrm{val}), \quad$ diakses 17 Maret 2017.

Simarmata, Sondang. 2012. Perilaku Merokok Pada Siswa-Siswi Madrasah Tsanawiah Negeri Model Kuok Kecamatan Bangkinang Barat Kabupaten Kampar Provinsi Riau Tahun 2012. Naskah Publikasi. Jakarta: FKM, (Online), (http://lib.ui.ac.id/opac/ themes/green/detail.jsp?id=2 0314693\&lokasi=lokal), diakses 10 Oktober 2016.

Sukmana, Teddie. 2011. Mengenal Rokok dan Bahayanya. Depok: Be 
Champion, (Online), (https://books. google.co.id), diakses 11 Juli 2017.

Sunaryo. 2013. Psikologi Untuk Keperawatan Edisi 2. Jakarta: EGC

Swarjana, I Ketut. 2015. Metodologi Penelitian Kesehatan. Yogyakarta: CV Andi Offset.

The Tobacco Atlas. 2015. The Tobacco Atlas Fifth Edition, (Online),

(http://www.tobaccoatlas.org ). Diakses 28 Mei 2017.

Vivaldi, Adin. 2016. Hubungan Status Merokok Orang Tua Terhadap Perilaku Merokok Mahasiswa Pria Teknuk Sipil Di Universitas Muhammadiyah Yogyakarta. Naskah Publikasi. Yogyakarta: FKIP, (Online), (http://repository. umy.ac.id), diakses 3 Juni 2017.
WHO. 2015. Fact Sheet: Perilaku Berisiko Kesehatan pada Pelajar SMP dan SMA di Indonesia, (Online), (http://apps.who.int/chp /gshs/2015_Indonesia_GSHS _Fact_Sheet_Bahasa.pdf), diakses 14 Januari 2017.

Xu, Xiang-Long., dkk. 2014. Smoking Attitudes Between Smokers And Non-Smoker Secondary School Students In Three Geographic Areas Of China: A Cross-Sectional Survey Based On Social Cognitive Theory. Jurnal Kesehatan, (Online), 78-79, (http://search. proquest.com/docview/17282 98146/fulltextPDF/E732CB A33E8041BBPQ/1?accounti $\mathrm{d}=38628$ ), diakses 12 Mei 2017. 